\title{
Relationship between seedling and mature vegetation on the hilly-gullied Loess Plateau
}

\author{
Yan-feng Jia ${ }^{1,3}$, Ju-ying Jiao ${ }^{1,2^{*}}$, Ning Wang ${ }^{1,3}$ \\ From 2010 International Conference on Combating Land Degradation in Agricultural Areas (ICCLD'10) \\ Zi'An City, PR China. 11-15 October 2010
}

\begin{abstract}
Seedling is an indispensable stage in plant cycle life, and seedling survival is important during natural vegetation restoration, especially on the Loess Plateau. In 2007, we selected 4 plots of Artemisia scoparia communities (ASC) and 4 plots of Artemisia gmelinii + Artemisia giraldii communities (AGC), examined seedling richness, diversity during the rainy season, and examined mature vegetation richness, coverage, and frequency in August. The results showed that seedlings density of ASC were $29 \mathrm{n} \mathrm{m}^{-2}, 33 \mathrm{n} \mathrm{m}^{-2}, 20 \mathrm{n} \mathrm{m}^{-2}$ and $31 \mathrm{n} \mathrm{m}^{-2}$ in July to October respectively, and that of AGC were $14 \mathrm{n} \mathrm{m}^{-2}, 12 \mathrm{n} \mathrm{m}^{-2}, 6 \mathrm{n} \mathrm{m}^{-2}$ and $9 \mathrm{n} \mathrm{m}^{-2}$ respectively; A. scoparia seedlings represented $53.2 \%$ of the total seedlings in ASC, the dominant species in AGC only account for less than $5 \%$ of the total seedlings. Most of the seedlings found were belonged to Compositae, Leguminoseae and Gramineae; $80 \%$ of seedlings in ASC were mainly comprised of A. scoparia and Lespedeza davurica, while in AGC that consisted of more than 6 species, such as L. davurica, Sophora viciifolia, Dracocephalum moldavicaand, A. gmelinii, Patrinia heterophylla, Heteropappus altaicus so on. Sørensen similarity index between monthly seedlings was approximately 0.47 in ASC and 0.35 in AGC; Sørensen similarity index between seedlings and mature vegetation ranged from 0.18 to 0.34 in ASC, and varied from 0.26 to 0.39 in AGC. These results suggested that seedling establishment would be a bottleneck for natural vegetation restoration when seed supply and seedling emergence were possible.
\end{abstract}

\section{Introduction}

The Loess Plateau is well known as one of the most rapidly eroding areas in the world, with average soil losses of $3,720 \mathrm{t} \mathrm{km}^{-2} \mathrm{a}^{-1}[1]$. For such a serious soil erosion area, reducing soil erosion is an important and urgent issue. Vegetation is one of the most efficient methods to control soil loss and ameliorate ecological environment $[2,3]$. However, widespread tree planting just retained significant tree cover in less than $10 \%$ of the total area [4]. Furthermore, planted trees and grasses take up soil water from deep soil layers and cause soil desiccation in the longer-term $[5,6]$. The restoration of nature vegetation is the most important measure to improve the ecological conditions on the Loess Plateau [7].

Sufficient seed in the soil seed back is important for recovery, but the germination of seeds and survival of

\footnotetext{
* Correspondence: jyjiao@ms.iswc.ac.cn

${ }^{1}$ Institute of Soil and Water Conservation, Chinese Academy of Sciences and Ministry of Water Resources, Yangling, Shaanxi, 712100, China

Full list of author information is available at the end of the article
}

seedlings are constrained by several environment factors [8]. In the hilly-gullied Loess Plateau, the seed density of soil seed bank ranged from 1,067 seeds $\mathrm{m}^{-2}$ to 14,967 seeds $\mathrm{m}^{-2}$ in $0-10 \mathrm{~cm}$ layer $[9,10]$, it is within the range reported by other studies on the grassland in the United States, Canada, Europe, and Japan with seed bank density varied from 287 seeds $\mathrm{m}^{-2}$ to 31344 seeds $\mathrm{m}^{-2}$ [11,12]. Seed density of the soil seed bank in the hilly-gullied Loess Plateau represented a medium level of soil seed bank, and concluded that the seed bank is large enough to allow natural restoration [13].

However, in the life history of plants, seed and seedling stages are particularly vulnerable to environmental conditions $[14,15]$. The dynamic of these stages influence the structure of both adult populations and communities [16]. And seedling recruitment represents a bottleneck for most populations [17]. Recruitment dynamics can be a key determinant of plant population growth and persistence [18], the success of regeneration of natural vegetation largely depends on the success of seedling survival

\section{SpringerOpen ${ }^{\circ}$}


and establishment, especially in harsh environment. And the aim of this study was to check: (1) differences in seedling density and species of different communities, (2) the similarity between seedlings in the continuous months to evaluate the seedling persistence, (3) the similarity between seedlings and the standing vegetation to evaluate the contribution of seedlings made to the mature vegetation.

\section{Method}

\section{Study site}

Zhifanggou watershed, located in the northern Shaanxi province, was selected as study site $\left(E 109^{\circ} 13^{\prime} 46^{\prime \prime}-109^{\circ}\right.$ $\left.16^{\prime} 03^{\prime \prime}, \mathrm{N} 36^{\circ} 42^{\prime} 42^{\prime \prime}-36^{\circ} 46^{\prime} 28^{\prime \prime}\right)$. The elevation ranges from $1,041.5 \mathrm{~m}$ to $1,425.71 \mathrm{~m}$ and $80.29 \%$ of the slopes have a gradient greater than $15^{\circ}$ [19]. The climate is characterized by cold, dry winters and warm, moist summers, and the mean temperature is approximately $8.8{ }^{\circ} \mathrm{C}$. The average annual precipitation is approximately $500 \mathrm{~mm}$, and $74 \%$ of rainfall occurs between June and September. The study area is in the temperate forest-steppe zone [20], but due to long-term human activity, most of the natural vegetation has been replaced by cultivated land for maize (Zea mays), millet (Panicum miliaceum) and potatoes (Solanum tuberosum) since the 1950s [21,22]. The forests are dominated by artificial Robinia pseudoacacia, and the shrubland is dominated by artificial Caragana korshinskii, artificial Hippophae rhamnoides and natural Sophora viciifolia. The steppe vegetation is mainly comprised of Artemisia gmelinii, Artemisia giraldii, Lespedeza davurica and Stipa bungeana [23].

\section{Vegetation analysis}

Field investigations were conducted in 2007. We selected two typical communities during natural succession process for investigation; one was Artemisia scoparia community (ASC) in early stage and another was A. gmelinii + A. giraldii community (AGC) in later stage, and 4 plots in each type were used. The quadrates size was $50 \mathrm{~cm} \times 50 \mathrm{~cm}$ for seedlings and $1 \mathrm{~m} \times 1 \mathrm{~m}$ for mature vegetation. During the rainy season (from July to October), seedlings richness and diversity were examined each month, and mature vegetation richness, coverage, and frequency were examined in August. Then we compared the seedlings density and seedling composition of each month with that of next month, and compared the seedling composition with that of mature vegetation.

The diversity indexes were calculated using the following formulas [24]:

$$
\begin{aligned}
& d_{M a}=(s-1) / \ln N \\
& H^{\prime}=-\sum\left(P_{i} \log P_{i}\right)
\end{aligned}
$$

$$
J_{s w}=H^{\prime} / \log S
$$

Where $d_{M a}$ is Margalef index, $H^{\prime}$ is Shannon-Wiener index, $J_{s w}$ is Pielou index, $N$ is the total number of individuals, $P_{i}$ is the number of individuals of one species in relation to the number of individuals in the population, $S$ is the total number of species in the sample.

Sørenson's index of similarity [25] was used to calculate the similarity between monthly seedlings, and the similarity between seedlings and the standing vegetation:

$$
C C=2 W /(A+B)
$$

Where $C C$ is Sørenson similarity, $A$ and $B$ are the number of all the species found in the two samples, and $W$ is the number of species found in both samples.

\section{Results}

\section{Seedlings density}

Seedlings in ASC were more than that in AGC in each month, while significant different only arisen in August and September (Figure 1). From July to October, seedlings of ASC were $29 \mathrm{n} \mathrm{m}^{-2}, 33 \mathrm{n} \mathrm{m}^{-2}, 20 \mathrm{n} \mathrm{m}^{-2}$ and 31 $\mathrm{n} \mathrm{m}^{-2}$, respectively, which were most in August and least in September; while seedlings of AGC were most in July and least in September, and seedlings densities were $14 \mathrm{n} \mathrm{m}^{-2}, 12 \mathrm{n} \mathrm{m}^{-2}, 6 \mathrm{n} \mathrm{m}^{-2}$ and $9 \mathrm{n} \mathrm{m}^{-2}$, respectively. But there was no significant difference between months in each community.

From July to October, the dominant species $A$. scoparia with seedling density of $9 \mathrm{n} \mathrm{m}^{-2}, 19 \mathrm{n} \mathrm{m}^{-2}, 9 \mathrm{n} \mathrm{m}^{-2}$ and $25 \mathrm{n} \mathrm{m}^{-2}$, respectively, which represented $30.4 \%, 55.8 \%$, $44.9 \%$ and $81.6 \%$ of the total seedlings in ASC. In AGC, the dominant species A. gmelinii appeared in July, September and October with density of $1.5 \mathrm{n} \mathrm{m}^{-2}, 0.3 \mathrm{n} \mathrm{m}^{-2}$ and $0.3 \mathrm{n} \mathrm{m}^{-2}$, respectively; seedlings of the other dominant species $A$. giraldii just were found in July and October with density of $0.2 \mathrm{n} \mathrm{m}^{-2}$ and $0.2 \mathrm{n} \mathrm{m}^{-2}$, respectively. Both of the dominant species seedlings represented less than $10 \%$ of the total seedlings in each month (Figure 2).

These were consistent with the composition of the soil seed bank. In soil seed bank, $A$. scoparia had the biggest density of 6888.7 seed $\mathrm{m}^{-2}$, which could take approximately $84.8 \%$ of the total seed in the soil seed bank. A. gmelinii with lower density of approximately 297.5 seed $\mathrm{m}^{-2}$ accounted for $2 \%$ of the total seed in soil seed bank, and A. giraldii with density of approximately 103.3 seed $\mathrm{m}^{-2}$ only accounted for $0.7 \%$ of the total seed in soil seed bank [26].

\section{Seedlings species and seedlings diversity}

From July to October, 22 species seedlings in 9 families were found in ASC, most of them were belonged to Compositae (6 species), Gramineae (5 species) and Leguminoseae ( 3 species); and 32 species in 13 families were 

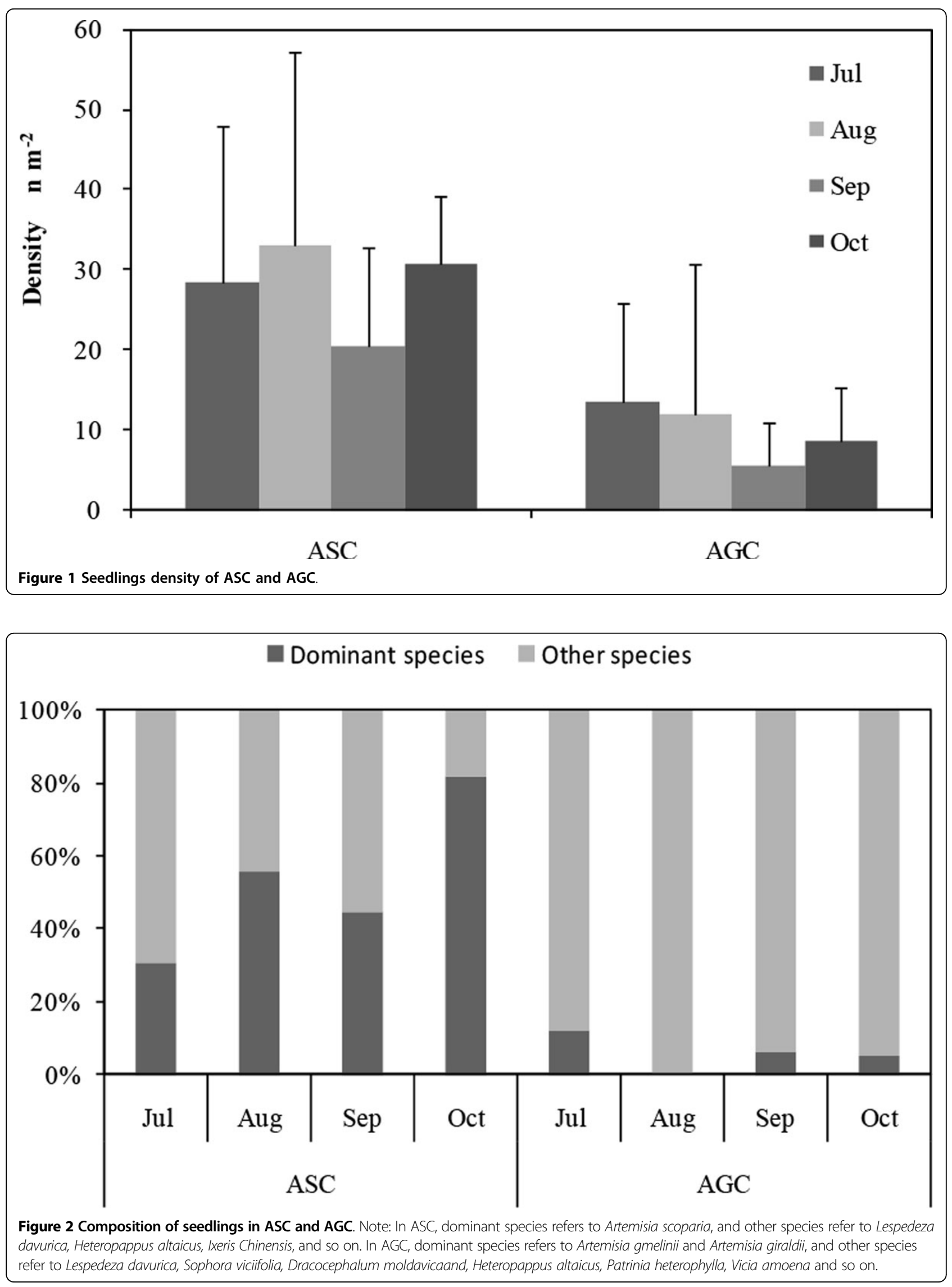
found in AGC, $50 \%$ of them were contained in Compositae (9 species) and Leguminoseae (7 species).

Seedlings of ASC were mainly composited by A. scoparia and $L$. davurica, and the first two main species constituted $64.6 \%$ to $89.7 \%$ of the total seedlings; while $80 \%$ of seedlings in AGC would consist of more than 6 species, such as L. davurica, S. viciifolia, Dracocephalum moldavicaand, A. gmelinii, Patrinia heterophylla, Heteropappus altaicus and so on (Table 1).

Seedlings diversity also suggested that AGC exhibited higher species richness. Diversity indexes of AGC were always higher than that of ASC (Figure 3). For example, in July, Margalef index, Pielou index, and Shannonwiener index of ASC were 2.69, 0.75 and 1.72, of AGC was $6.56,0.81$ and 2.33 , and in October, the three indexes of ASC were 2.62, 0.34 and 0.78, and in AGC were $8.88,0.90$ and 2.70 .

\section{Similarity between monthly seedlings}

The average similarity index of ASC was 0.47 , ranging from 0.39 to 0.61 , and the similarity index decreased from July to October; while the average similarity index in AGC was 0.35, ranging from 0.26 to 0.46 , with an increase trend (Figure 4).

L. davurica, D. moldavicaand and A. scoparia appeared each month in ASC, while Euphorbia humifusa was found in both of July and August, Salsola collina was found in July, August and September, Poa sphondylodes and Potentilla tanacetifolia were found both in September and October (Table 2). In AGC, species appeared in each

Table 1 Seedlings species of ASC and AGC

\begin{tabular}{|c|c|c|}
\hline Types & Mouth & Three main species (\%) \\
\hline & Jul & $\begin{array}{l}\text { Lespedeza davurica }(34.2 \%) \\
\text { Artemisia scoparia }(30.4 \%) \\
\text { Potentilla tanacetifolia }(7.9 \%)\end{array}$ \\
\hline \multirow[t]{4}{*}{ ASC } & Aug & $\begin{array}{l}\text { Artemisia scoparia (55.8\%) } \\
\text { Lespedeza davurica (30.4\%) } \\
\text { Ixeris Chinensis (3.8\%) }\end{array}$ \\
\hline & Sep & $\begin{array}{l}\text { Lespedeza davurica }(40.8 \%) \\
\text { Artemisia scoparia }(44.9 \%) \\
\text { Lappula myosotis }(6.9 \%)\end{array}$ \\
\hline & Oct & $\begin{array}{l}\text { Artemisia scoparia (81.6\%) } \\
\text { Lespedeza davurica (8.1\%) } \\
\text { Heteropappus altaicus (3.0\%) }\end{array}$ \\
\hline & Jul & $\begin{array}{l}\text { Cleistogenes squarrosa }(21.3 \%) \\
\text { Lespedeza davurica }(18.1 \%) \\
\text { Artemisia gmelinii }(11.3 \%)\end{array}$ \\
\hline \multirow[t]{3}{*}{$A G C$} & Aug & $\begin{array}{l}\text { Sophora viciifolia (71.9\%) } \\
\text { Lespedeza davurica (18.3\%) } \\
\text { Dracocephalum moldavicaand (2.8\%) }\end{array}$ \\
\hline & Sep & $\begin{array}{l}\text { Lespedeza davurica (29.9\%) } \\
\text { Dracocephalum moldavicaand (11.9\%) } \\
\text { Astragalus scaberrimus (11.9\%) }\end{array}$ \\
\hline & Oct & $\begin{array}{l}\text { Lespedeza davurica }(10.8 \%) \\
\text { Ixeris Chinensis }(18.6 \%) \\
\text { Artemisia scoparia }(5.9 \%)\end{array}$ \\
\hline
\end{tabular}

month were $L$. davurica, S. viciifolia and D. moldavicaand. Vicia amoena was found both in July and August. 8 other species appeared both in September and October, except for L. davurica, S. viciifolia and D. moldavicaand. There were some owerwintering seedlings appeared both in September and October, such as Cleistogenes squarrosa, Bothriospermun secundum, Viola dissecta and A. gmelinii (Table 2). Compared with AGC, less seedlings species were found in ASC, but the species composition kept relative stable; in contrary, more seedling species were found in AGC, but the composition changed more frequently.

In ASC, density of seedlings decreased after September, except A. scoparia. At the end of rain season, two species had a higher density, density of $A$. scoparia seedling was $25.2 \mathrm{n} \mathrm{m}^{-2}$ and density of $L$. davurica seedling was $2.5 \mathrm{n} \mathrm{m}^{-2}$ (Table 2), which may go through the winter and grow up in the next year. But at the end of growing season, nearly all of the seedling densities in AGC were less than $1 \mathrm{n} \mathrm{m}^{-2}$ (Table 2), whether these seedlings would survival in the next spring needs more investigation.

\section{Similarity between seedlings and vegetation}

In ASC, the Sørenson's index of similarity between seedlings and mature vegetation was $0.34,0.18,0.26$ and 0.32 , respectively. And in AGC, the similarity index was $0.30,0.27,0.26$ and 0.39 , respectively (Figure 5 ). The Sørenson's index of similarity in AGC was higher than that of ASC, but no significant different existed. During the investigation, species in standing vegetation was relative stable, which meant that $A$ in Sørenson index formula was relative stable. Then the Sørensen similarity index between seedling and mature vegetation largely depended on seedling species. When a new seed germination and survival, $B$ in Sørenson index formula increased, and $W$ in Sørenson index formula would have a chance to increase, and the similarity index would rise. Standing vegetation species in AGC were more than that of ASC, and as a result, there would be more kinds of seeds produced and more kinds of seedlings found.

However, the higher similarity index in AGC did not mean seedlings could make more contribution to the community. Seedlings appeared in AGC of each month were $L$. davurica, $D$. moldavicaand and S. viciifolia, they were not the dominant species in AGC. Although the dominant species A. gmelinii and A. giraldii companied with seedling at the end of the growing season, only 3 A. gmelinii seedlings and 2 A. giraldii seedlings survived in $10 \mathrm{~m}^{2}$. It is difficult for these seedlings to establish a community, in which density of A. gmelinii was $3 \mathrm{n} \mathrm{m}^{-2}$ and density of $A$. giraldii was $2 \mathrm{n} \mathrm{m}^{-2}$. This would be the result of different reproduction types. In ASC, the dominant species $A$. scoparia reproduces only by seed, while the dominant species $A$. gmelinii and $A$. giraldii in 

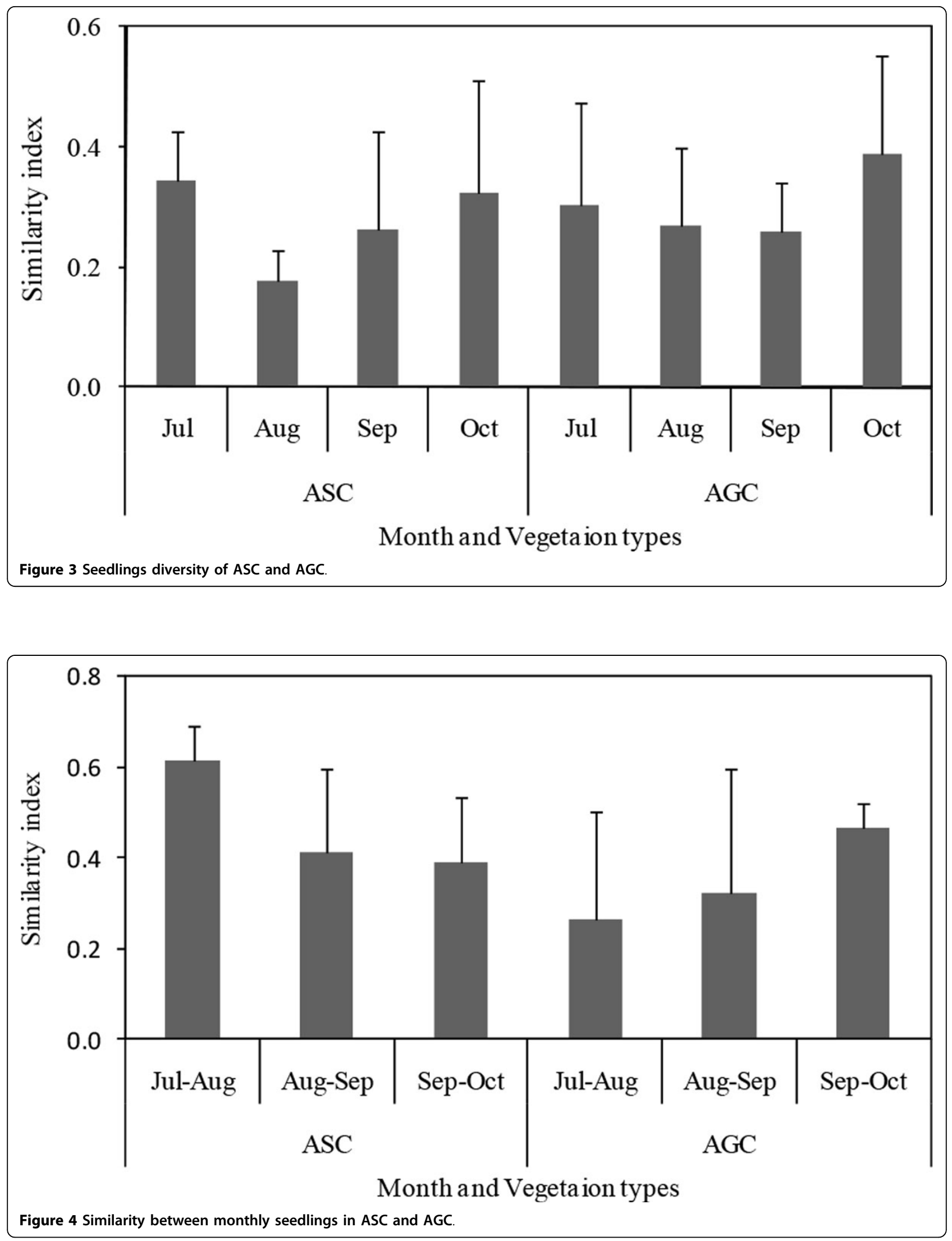
Table 2 Seedlings species of dynamic and final density

\begin{tabular}{|c|c|c|c|c|c|}
\hline \multirow[t]{2}{*}{ Types } & \multirow[t]{2}{*}{ Specise } & \multicolumn{3}{|c|}{ Month } & \multirow{2}{*}{$\begin{array}{l}\text { Final density } \\
\left(\mathrm{N} \mathrm{m}^{-2}\right)\end{array}$} \\
\hline & & $7-8$ & $8-9$ & $9-10$ & \\
\hline & Lespedeza davurica & + & - & - & 2.5 \\
\hline & Euphorbia humifusa & - & - & & 0 \\
\hline & $\begin{array}{l}\text { Dracocephalum } \\
\text { moldavicaand }\end{array}$ & - & - & - & 0.2 \\
\hline \multirow[t]{9}{*}{ ASC } & Salsola collina & / & - & - & 0 \\
\hline & Artemisia scoparia & + & - & + & 25.2 \\
\hline & Potentilla tanacetifolia & & & / & 0.2 \\
\hline & Poa sphondylodes & & & - & 0.2 \\
\hline & Lespedeza davurica & - & - & - & 0.9 \\
\hline & Sophora viciifolia & + & - & + & 0.5 \\
\hline & $\begin{array}{l}\text { Dracocephalum } \\
\text { moldavicaand }\end{array}$ & - & + & - & 0.3 \\
\hline & Vicia amoena & + & - & + & 0.7 \\
\hline & Artemisia gmelinii & - & + & - & 0.3 \\
\hline \multirow[t]{6}{*}{ AGC } & $\begin{array}{l}\text { Bothriospermun } \\
\text { secundum }\end{array}$ & & & + & 0.2 \\
\hline & Cleistogenes squarrosa & & & / & 0.2 \\
\hline & Artemisia hedinii & & & - & 0.1 \\
\hline & Viola dissecta & & & + & 0.3 \\
\hline & Caragana korshinskii & & & + & 0.3 \\
\hline & Ixeris Chinensis & & & + & 1.6 \\
\hline
\end{tabular}

Note: "+" means increase; "_" means decrease; "/" means stable.

AGC reproduces not only by seed but also by rhizomatous [27]. In harsh environment, vegetable propagation reproduction would be the principal way to spreads, which would help vegetative reproduction ramets to beat seed seedlings, then invade and establish successfully [27].

\section{Conclusions}

Compared with A. gmelinii + A. giraldii communities (AGC), A. scoparia communities (ASC) had a higher seedling density and the seedling of dominant species could take approximately $53.2 \%$ of the total seedlings. Thousands of seeds existed in soil seed bank and these seeds germinated continuously to keep the seedling density stable. Until the end of the growing season, the survival seedlings density was similar to the standing vegetation. This suggested that $A$. scoparia communities (ASC) may be established by countless seeds germinated and left some lucky seedling to survival.

In contrary, A. gmelinii + A. giraldii communities (AGC) contained more species in seedlings. But the two dominant species constituted less than $5 \%$ of the total seedlings. A. gmelinii and A. giraldii seedlings could not found in each month, at the end of the growing season, only 2 A. giraldii seedlings and 3 A. gmelinii seedlings were survival in $10 \mathrm{~m}^{2}$, which was lower than the mature vegetation density. This may caused by the scarce seed in
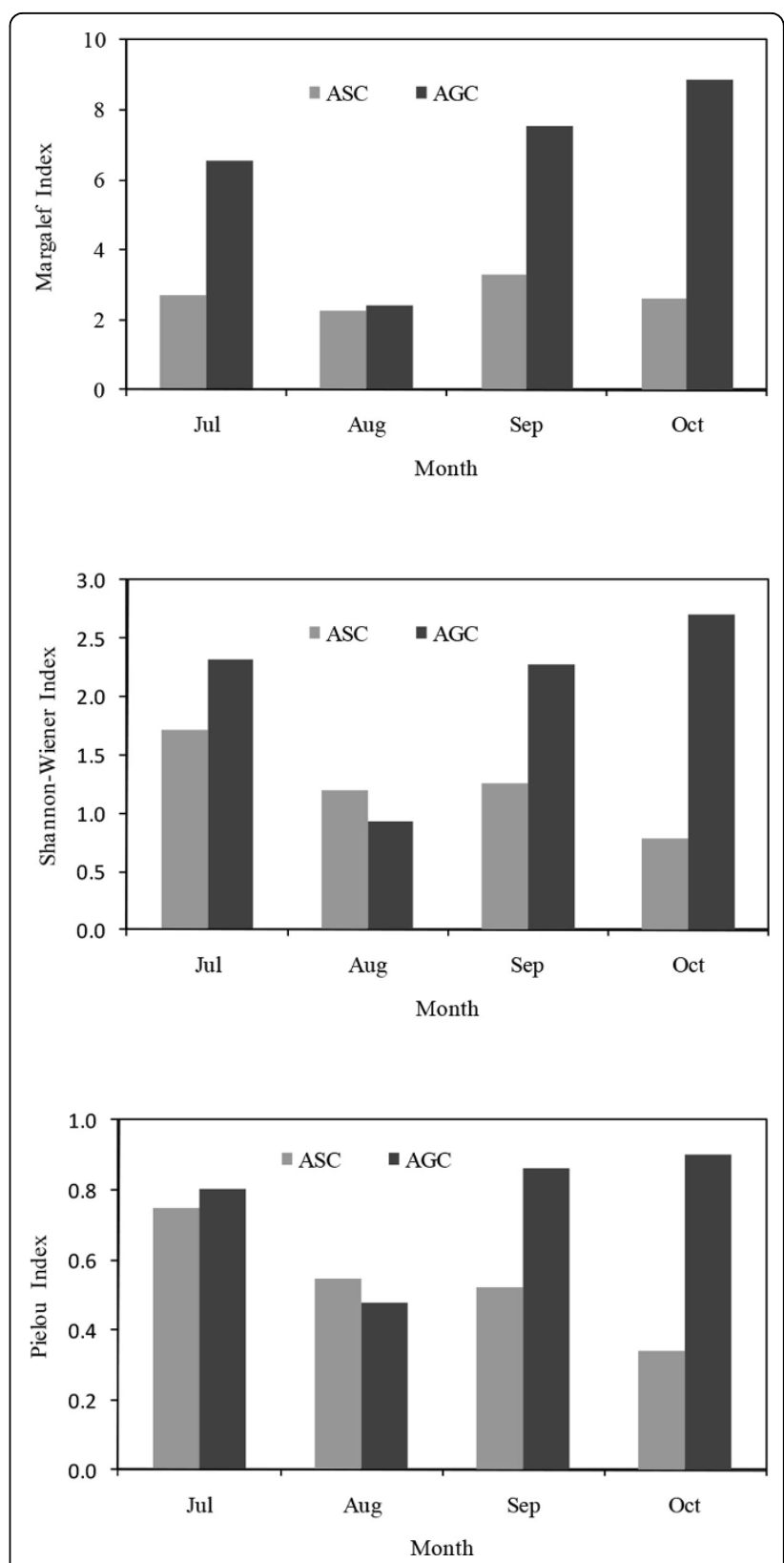

Figure 5 Similarity between seedlings and mature vegetation in ASC and AGC.

soil seed bank and the reproduction strategy. A. gmelinii and $A$. giraldii may not establish only by seed germination, and vegetable propagation reproduction would be more important.

Competing interests

The authors declare that they have no competing interests.

\section{Acknowledgements}

This study was sponsored by the National Natural Sciences Foundation of China (40771126) and innovation projects of Northwest A \& F University 
(CX200906). The authors are grateful for assistance from the Ansai Ecological Experimental Station of Soil and Water Conservation, CAS.

\section{Declarations}

The publication costs for this article were funded by Scientific \& Technical Development Inc.

This article has been published as part of SpringerPlus Volume 2 Supplement 1, 2013: Proceedings of the 2010 International Conference on Combating Land Degradation in Agricultural Areas (ICCLD'10). The full contents of the supplement are available online at http://www.springerplus.com/ supplements/2/S1.

\section{Authors' details}

'Institute of Soil and Water Conservation, Chinese Academy of Sciences and Ministry of Water Resources, Yangling, Shaanxi, 712100, China. Institute of Soil and Water Conservation, Northwest A\&F University, Yangling, Shaanxi, 712100, China. ${ }^{3}$ Graduate School of Chinese Academy of Sciences, Beijing, China.

\section{Published: 11 December 2013}

\section{References}

1. Goldman SJ, Jackson K, Bursztynsky TA: Erosion and Sediment Control Handbook. McGraw Hill Book Company, New York; 1986.

2. Zhaoyin Wang, Guangqian Wang, Guohe Huang: Modeling of state of vegetation and soil erosion over large areas. International Journal of Sediment Research 2008, 23(3):181-196, September.

3. Junliang Tian: Restoring the eco-environment in conformity natural lawsome considerations on the vegetation restoration on the Loess Plateau. Bulletin of Chinese Academy of Sciences 2002, 17(4):286-288, June.

4. Jun Li, Bing Chen, Xiaofang Li, Yujuan Zhao, Yangjing Ciren, Bin Jiang, Wei Hu, Jimin Cheng, Mingan Shao: Effects of deep soil desiccation on artificial forestlands in different vegetation zones on the Loess Plateau of China. Acta Ecologica Sinica 2008, 28(4):1429-1445, April.

5. Hongsong Chen, Mingan Shao, Yangyang Li: Soil desiccation in the Loess Plateau of China. Geoderma 2008, 143(1-2):91-100, January.

6. Jintun Zhang: Succession analysis of plant communities in abandoned croplands in the eastern Loess Plateau of China. Journal of Arid Environments 2005, 63(2):458-474, October.

7. Pirjo Welling, Anne Tolvanen, Kari Laine: The alpine soil seed bank in relation to field seedlings and standing vegetation in subarctic Finlan. Arctic, Antarctic, and Alpine Research 2004, 36(2):229-238, June.

8. Wenjuan Bai, Jonathan Mitchley, Juying Jiao: Soil Seed Bank and Standing Vegetation of Abandoned Croplands on Chinese Loess Plateau: Implications for Restoration. Arid Land Research and Management 2010, 24(2):98-116, April.

9. Ning Wang, Yanfeng Jia, Wenjuan Bai, Zhenguo Zhang, Juying Jiao: The character and dynamics with season of soil seed banks in abandoned croplands of loess gully region. Acta Prataculturae Sinica 2009, 18(3):43-52, June.

10. Rice KJ: Grassland. Ecology of soil seed banks. Academic Press, New York;M. A. Leek, V. T. Parker, R. L. Simpson 1989:211-230.

11. Beatrijs Bossuyt, Olivier : Can the seed bank be used for ecological restoration? An overview of seed bank characteristics in European communities. Journal of Vegetation Science 2008, 19(6):875-884, December.

12. Meizhen Liu, Gaoming Jiang, Shunli Yu, Yonggeng Li, Gang Li: The Role of Soil Seed Banks in Natural Restoration of the Degraded Hunshandak Sandlands, Northern China. Restoration Ecology 2008, 17(1):127-136, April.

13. E. Symonides: Population of Spergula vernalis Willd. on dunes in the Torun Basin. Ekologia Polska 1974, 22:379-416.

14. John L. Harper: Population Biology of Plants. Academic Press, New York 1977.

15. Guàrdia R, Gallart F, Ninot JM: Soil seed bank and seedling dynamics in badlands of the Upper Llobregat basin (Pyrenees). Catena 2000 40(2):189-202, June.

16. Jessica Gurevitch, Scheiner Samuel M., Fox Gordon A.: The Ecology of plant. Sinauer Associates, Massachusetts 2002

17. Forbis Tara A., Doak Daniel F.: Seedling establishment and life history trade-offs in alpine plants. American Journal of Botany 2004, 91(7), July.

18. Bicheng Li: Monitoring by remote sensing of water and soil loss and it comprehensive treatment on watershed. Science Press, Beijing; 1995.
19. CCCV (Compiling Committee of Chinese Vegetation). Chinese vegetation, Science Press, Beijing; 1980.

20. Bicheng Li, Zhao GS, Xilu Hou, Ma XM, Ma XY: The experimental study on land resource evaluation and optimal utilization model in Zhifanggou gully watershed. Studies of ecological agriculture with soil and water conservation in Loess Hilly Gully Region. Institute of Soil and Water Conservation Yangling, Tianze Eldonjo; 1990.

21. Guoliang Wang: The characteristic of plant community and its effect on soil moisture and nutrition in Zhifanggou watershed. Institute of Soil and Water Conservation, Chinese Academy of Sciences and Ministry of Water Resources Yangling; 2002

22. Bojie Fu, Zhang QJ, Liding Chen, Zhao WW, Gulinck H, Guobin Liu, Qinke Yang, Zhu YG: Temporal change in land use and its relationship to slope degree and soil type in a small catchment on the Loess Plateau of China. 2006, 65(1):41-48, month.

23. Ming Dong: Survey, observation and analysis of terrestrial biocommunities. Standards Press of China Beijing; 1996.

24. Sørenson T: A method of establishing groups of equal amplitude in plant sociology based on similarity of species content and its application to analyses of the vegetation on Danish commons. Biologiske Skrifter (Kongelige Danske Videnskabernes Selskab) 1948, 5(4):1-34, 1948.

25. Ning Wang: Effects of slope-gully erosion environment on the propagule and seedling establishment -a case study in zhifanggou ansai on loess plateau. Northwest A\&F University Yangling; 2008.

26. Feng Du, Lun Shan, Zongsuo Liang, Xuexuan Xu: Studies on the succession niche of abandoned arable land in a hilly Loess region of northern Shaanxi province. Acta Prataculturae Sinica 2006, 15(3):27-35, June.

27. Dayong Zhang: Plant Life-History Evolution and Reproductive Ecology. Science Press, Beijing; 2003.

doi:10.1186/2193-1801-2-S1-S17

Cite this article as: Jia et al:: Relationship between seedling and mature vegetation on the hilly-gullied Loess Plateau. SpringerPlus 2013

2(Suppl 1):S17.

\section{Submit your manuscript to a SpringerOpen ${ }^{\circ}$ journal and benefit from:}

- Convenient online submission

- Rigorous peer review

- Immediate publication on acceptance

- Open access: articles freely available online

- High visibility within the field

- Retaining the copyright to your article

Submit your next manuscript at $>$ springeropen.com 